症例

腸間膜内膿瘍を生じ，ドレナージのみで治癒したCrohn 病の 1 例

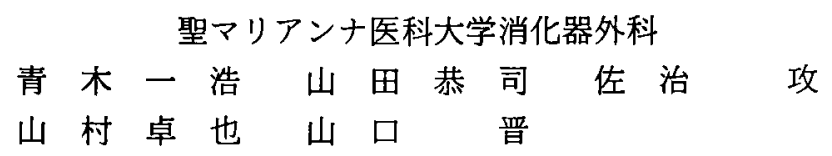

Crohn 病に合併した腸間膜内膿瘍の 1 症例を経験した。患者は41歳, 男性. 過去に Crohn 病による腸閉塞で小腸切除術を受けていた，発熱腹痛があり，外来受診し精査加 療目的で入院となり入院時腹部 CT で腹腔内膿瘍を疑った．抗生剤治療を行うが高熱が 持続し, 腹部 CT にて膿瘍の増大がみられ，緊急手術を行った。手術所見では小腸間膜 起始部に発赤のある硬結を認め, 腸間膜内膿瘍と診断した。腸管との交通は認めず，切 開排膿ドレナージ施行し手術を終了した。術後経過良好で第29病日で退院した，術後経 過 4 年で無再発である. Crohn 病の合併症として瘦孔, 膿瘍は10〜20\%にみられ, 部位 では腸管腹壁肨場が最多とされる。腸間膜内膿晹の本邦報告例はわれわれが検索しえる 限りでは過去 20 年間で 9 例を数えるのみであった。瘦孔を伴わない腸間膜内膿演の報告 例は確認できず, 病変部腸管を切除せず単純ドレナージのみで治痹できた稀な例である ため報告した。

索引用語：Crohn 病, 腸間膜内膿㰾

\section{緒 言}

Crohn 病において腹腔内朖㿠を含む腹部膿瘍は早 期の診断と治療を要する合併症であるが，腸管腔との 連絡が認められない腸間膜内膿晅は稀である。その原 因は, Crohn 病の潰瘍は腸内腸間膜側の縌走潰瘍とし て存在することが多いが, その穿通では殆どが瘦孔を 合侀しているからである. 今回わ犰わ机は腸管との交 通を確認できないCrohn 病に合併した腸間膜内膿瘍 の1例を経験し, 単純ドレナージのみで治箅せしめた ため報告する。

\section{症例}

患者: 41歳, 男性.

主訴：腹痛。

家族歴：特記すべきことなし。

既往歴：9 年前にCrohn 病による腸閉塞で小腸切 除術を受け, 以降外来通院中であった。

現病歴: 平成11年 4 月10日より発熱, 咽頭痛等の感 冒様症状出現，4月14日朝から腹痛も出現し徐々に增

2004年 7 月 15 日受付 2004 年10月 5 日採用 〈所属施設住所〉

$\overline{\mathbf{T}} 216-8511$ 川崎市宮前区菅生 2-16-1
悪するため同日当院外来受診した．精査加療目的にて 即日入院となる.

入院時現症：身長 $175 \mathrm{~cm}$, 体重 $53 \mathrm{~kg}$, 血圧 $120 / 90$ $\mathrm{mmHg}$, 脈拍 $62 / \mathrm{min}$ 整, 体温 $38.4^{\circ} \mathrm{C}$, 意識清明, 嘔気 嘔吐なし，朣周囲に圧痛および軽度の反跳痛あるも， 筋性防御は認めなかった。

入院時血液検查所見 : WBC 10,300, T - Bil 2.7, CRP 10.5 と上昇を認めた。

入院時腹部単純 $\mathrm{X}$ 線検査（図 1 ）：大腸ガスと少量 の小腸ガスを認める他は腹水，石灰化等の異常所見を 認めない.

入院時腹部 CT 検査 (図 2 ): 骨盤入口部のほほ正 中, 右腸骨動静脈の前方に隔壁を伴い不均一に造影さ れる腫瘤像を認め, 膿瘍腔と思方九た。

入院後経過：Crohn病に合併した腹腔内膿瘍の診 断で入院後抗生剤による保存的治療を開始した。第 6 病日にて発熱の增強および WBC, CRP の增加あり, 追跡の腹部 CT (図 3 ) にて膿瘍の増大を認め, 緊急手 術となった。

手術所見：膿瘍は上腸間膜動脈起始部に近い腸間膜 内に存在し, 腸係蹄とは離れて存在していた。膿瘍に 最も近い小腸の部位は前回手術時の吻合部より $10 \mathrm{~cm}$ 


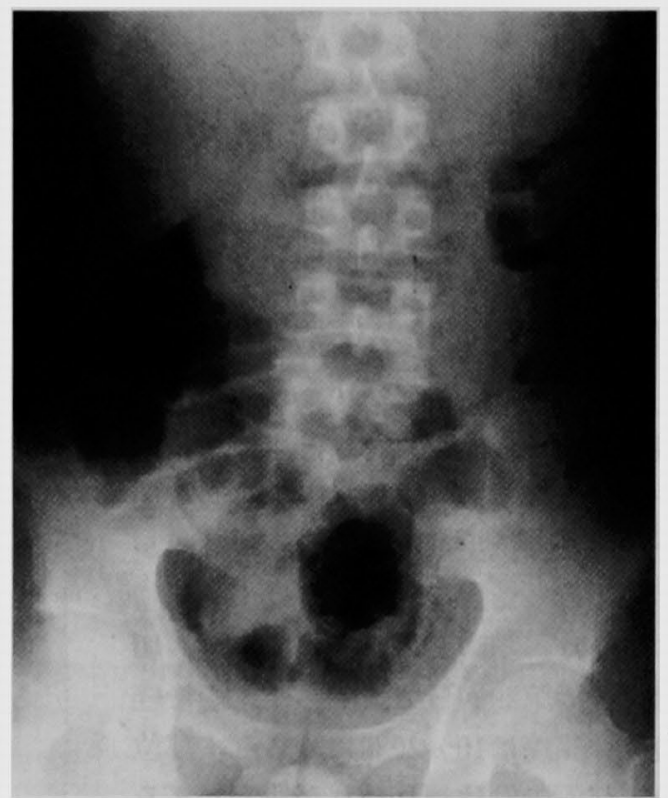

図 1 腹部単純 $\mathrm{X}$ 線写真：大腸ガスと少量の小 腸ガスを認める他は腹水, 石灰化等の異常所見 を認めない.

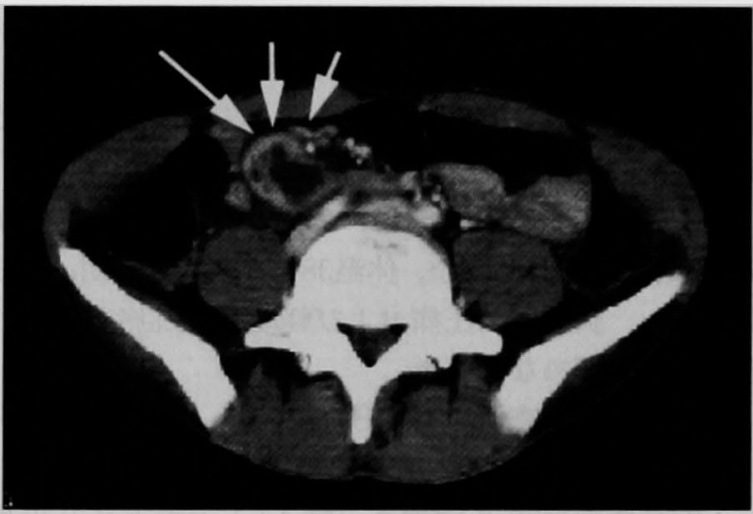

図 2 腹部造影 CT : 骨盤入口部のほぼ正中, 右腸骨動静 脈の前方に隔壁を伴い不均一に造影される腫瘤像を認 め膿瘍腔と思われた。

口側であった(図 4 ).入念に観察するも瘦孔は不明で, 外見的な腸管の炎症所見や狭窄は認められなかった。 また前回手術時に遺残された腹腔内異物などは認めら れなかった。前回手術時に腸切除されており, 残存小 腸が短かかったため腸切除は行わず，膿瘍ドレナージ のみ施行し，手術終了とした。

術後小腸造影検査 (図 5 )：前回手術時の吻合部近傍 に縦走潰瘍を認める他, 明らかな㿉孔形成, 狭窄等は 認められなかった。

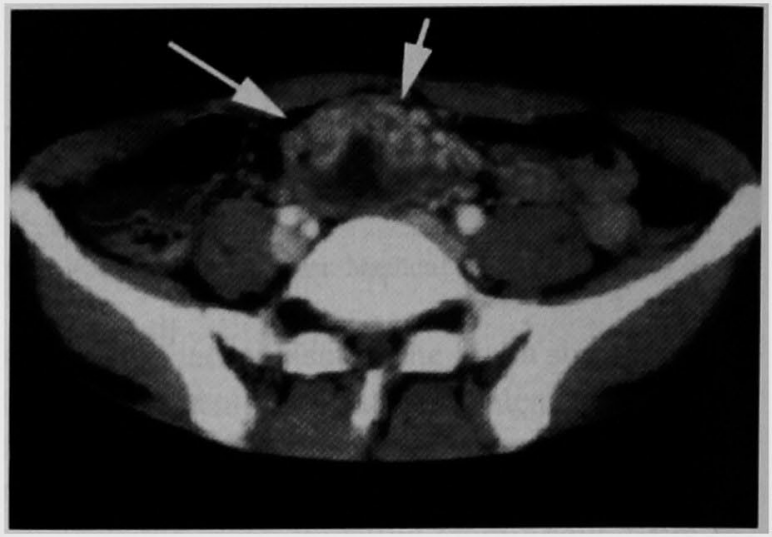

図 3 腹部造影 CT（入院後）：膿瘍の増大を認めた。

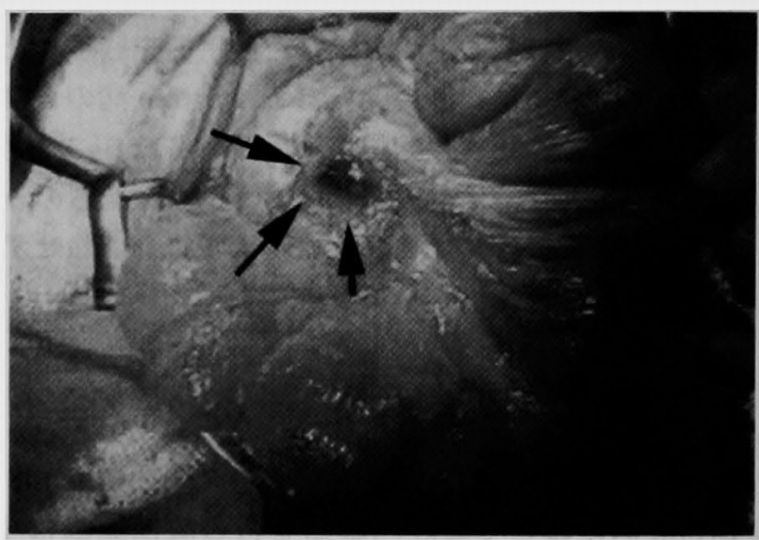

図 4 手術所見：膿瘍は上腸間膜動脈起始部に近い腸間 膜内に存在し,腸係蹄とは離れて存在していた.瘦孔は 不明で外見的な腸管の炎症所見などは認められなかっ た.膿瘍ドレナージのみ施行した。

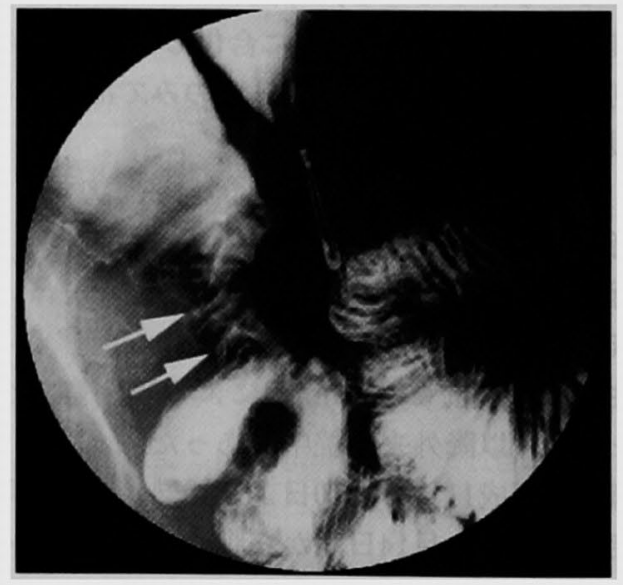

図 5 術後小腸造影検査: 前回手術時の吻 合部近傍に縦走潰瘍を認める他, 明らかな 瘦孔形成, 狭窄は認められなかった。 
術後経過：術後経過良好で第29病日で退院となっ た. 退院後行った大腸内視鏡による回盲部の観察では 白苔を有する小腸潰瘍が吻合部より $10 \mathrm{~cm}$ 口側に認め られた。術後 4 年経過したが腹部膿瘍の再発なく, 経 腸栄養療法にて経過観察中である。

\section{考察}

Crohn 病における腹部膿瘍の発生率は Keighley ら゙によれば12〜280。 おり，本邦においては八尾ら゙の報告で8.9\%みられた

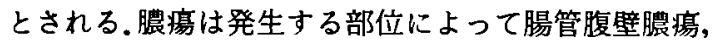

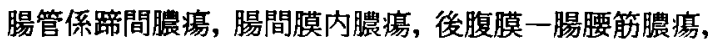
肝脾膿瘍に分類される。腸管腹壁膿湟が最も多くみら れ，腸間膜内膿瘍は病変部腸管の腸間膜内に限局した 膿瘍で非常に稀である゙．しかし，原田ららによれば 1999年までの11年間において腹腔内膿瘍中，腸間膜内 膿場は最多の 7 例を経験したと報告している。これは 近年の本邦におけるCrohn 病患者数の増加，内科的治 療期間の延長などに起因しているものと思われるが， 過去 20 年間の本邦報告例では他に 2 例を認めるのみで 瘻孔を伴わず単純ドレナージのみで治撚せしめた腸間 膜内浸場は確認できなかった。

虹瘍の原因は裂渾・潰瘍の穿通であるが，今回の症 例のように瘦孔の明らかでない例も稀であるがみられ $3^{6)}$. 腹腔内膿瘍は難治であり，腸間膜内膿場の場合に はドレナージ困難な例が多いため外科的切除が必須で あるとされる．Ricciら”によると，膿掦のドレナージ のみでは再発や瘦孔の形成をきたすためにドレナージ に加え病変部の切除を行うべきとしている.

原則として治療は外科手術による膿瘍のドレナージ 術を行う。この際に浸場の原因となった病変部の腸管 を同時に切除・吻合する一期的手術と後日腸切除を行 う二期的手術がある。患者の全身状態がよく，膿場腔 も大きくない症例には一期的手術を行うとされ る481. いずれにしても切除範囲を含めた手術方法につ いて確立されたものはなく，症例の積み重ねによるさ らなる検討が必要であろう。
本症例は膿瘍と腸管との明らかな瘦孔がなく膿場ド レナージのみで治瘛することができた４ 4 年経過した 現在においても再発がみられないことより瘦孔が明ら かでない腸間膜内膿場は単純ドレナージのみで治撚で きる可能性が考えられた。

\section{結 語}

Crohn 病に合併した瘦孔の明らかでない腸間膜内 膿瘍の 1 例を経験した。瘦孔が明らかでなく開腹単純 ドレナージのみで再発がみられなかった本症例は稀で あり，報告した。

\section{文献}

1) Keighley MRB, Eastwood D, Ambrose NS, et al: Incidense and microbiology of abdominal and pelvic abscess in Crohn's disease. Gastroenterology $83: 1271-1275,1982$

2) Huizenga $\mathrm{KA}$ : Gastrointestinal complications of ulcerative colitis and Crohn's disease. Inflammatory bowel disease. 3rd ed., Lea \& Febiger, Philadelphia, 1988, p257-280

3）八尾恒良, 岡田光男, 飯田三雄他：Crohn 病の長 期経過。消外 14:685-692，1992

4）杉田 昭：急性腹症最新の知見 2) Crohn 病. 外 科 $57: 1473-1478,1995$

5）原田博文, 杉田 昭, 嶋田 紘他：Crohn 病に合 併した腹腔内膿湟と下血の手術適応. 日腹部救急 医会誌 $20 ： 41-44,2000$

6) Steinberg DM, Cooke IVT, Williams JA : Abscess and fistulae in Crohn's disease. Gut 14 : 865-869, 1973

7) Ricci MA, Meyer $K K$ : Psoas abscess complicating Crohn's disease. Am J Gastroenterol $80: 970-977,1985$

8）鎌田喜代志, 金泉年郁, 上野正義他：腸腰筋腿瘍 を合併したCrohn 病の 1 例. 日臨外会誌 61 ： 1228-123', 2000 


\title{
A CASE OF CROHN'S DISEASE WITH AN INTRAMESENTERIC ABSCESS WITHOUT FISTULA TREATED BY SIMPLE DRAINAGE
}

\author{
Kazuhiro AOKI, Kyyoji YAMADA, Osamu SAJI, Takuya YAMAMURA and Susumu YAMAGUCHI \\ Department of Gastroenterological Surgery, St. Marianna University School of Medicine
}

We present a case of Crohn's disease with an intramesenteric abscess without fistula. The patient was a 41 -year-old man who had been performed a partial resection of the small intestine 9 years earlier for bowel obstruction caused by Crohn's disease. He had a 4-day history of low grade fever and abdominal pain, and was admitted to the hospital. Abdominal CT scan demonstrated an intraabdominal abscess. Although conservative therapy with antibiotics was started, high fever persisted. An emergency operation was performed. At laparotomy, an intramesenteric abscess was present, but no fistula was observed. Simple drainage for the abscess was carried out. The patient's postoperative course was uneventful, and he was discharged from the hospital on the 29th postoperative day. Abdominal abscess as a complication of Crohn's disease represents about 10 20 percent of all complications of the disease in the Japanese literature. Intramesenteric abscess, this is so rare that only a cases have been reported during recent 20 years, usually occurs due to perforation of ulcer of the small intestine. We report this case here because intramesenteric abscess associated with Crohn's disease without fistula is uncommon. 